\title{
Heritage - public and expert discourse in the process of heritigization
}

\author{
Kornelia Kajda
}

Institute of Archaeology, Adam Mickiewicz University, Poznań, Poland

\begin{abstract}
The debate about "Who owns the past?" has been and still is the subject heated discussion in heritage studies. Deciding what should be protected and what needs special social and governmental attention triggers many questions which are often met with equivocal answers. This article concentrates on a phenomenon framed as heritagization in relevant scholarship. The first section is devoted to the situations in which experts notify the public about the importance of places and historical events. Four case-studies will be discussed. The first two will touch upon cultural and natural heritage sites Jewish and German heritage in Poland and Rospuda Valley) and show how a group of experts can influence Polish society to build a positive atmosphere around neglected heritage in Poland. The next two case-studies (communist heritage in Poland and Białowieża Forest) present how the situation of conflict between experts and the public may influence the way in which heritage is understood by the society. The case studies will also show how the public renegotiates the meaning of heritage and designates what should be preserved.
\end{abstract}

Keywords: Heritigization, Poland, Natural Heritage, Cultural Heritage, Conflict

\section{Introduction}

In heritage studies, there has been an ongoing debate on the issues connected to the ownership of the past, heritage, and the social perception of heritage (see Carman 2005, George 2010, Hodder 2010, Kobyliński 2011, La Follette 2013). The multivocality and complexity of these matters makes it rather impossible to present the topics in their fullness (see Deisser \& Njuguna 2016). As the concept of heritage itself is hard to grasp, the meaning of it and its importance to different groups seem to be even more complicated. Something that may be considered as valuable heritage to some may be thought of as insignificant to others. The issues of forgotten, unwanted heritage (Harrison 2013) and heritage of a social margin, homeless heritage (Kiddey 2017), additionally prove how intricate the problems connected to heritage ownership, appropriation, construction or deconstruction can be.

Nonetheless, all the matters presented above strongly relate to creating heritage and they send us back to the very beginning of heritage, namely, the process of heritigization which involves any actions connected to appropriating, constructing heritage and presenting its importance in and to society (Margry 2011: 335, Milosevic 2017). This is a core process which is brought within the discourse of heritage and which, often unconsciously, is a starting point to any discussion about heritage. 
Taking into account four examples from Poland, this article will present how heritage may be acknowledged in a situation of its oblivion, endangerment or devastation. I will also address how heritigization may come from the public (bottom-up) as well as be inspired by the experts (top-down). These issues will be analyzed on basis of mutual actions of the public and the experts who work together to protect the common good, focusing attention on situations of heritage conflict between the public and the experts. To present the first issue, I will use the examples of Jewish and German heritage in Poland and the disagreements on the Rospuda Valley. The next two case studies will illustrate how a disagreeable situation between the experts and the public may influence the perception of heritage, its treatment, and how it can trigger social action.

\section{Heritage experts and society - who are they?}

The terms 'expert' and 'society' are very broad and may be understood in various ways. Discussing in depth the nature of the many different meanings of the two terms would strain from the aim of this work, therefore, I use the terms 'expert' and 'public' because they allow me to study the social aspects of heritage in its complexity. Additional problems that must be noticed in this section relates to the fact that when it comes to heritage matters, it is hard to define who is an expert and who is not. The 'non-experts' are connected to the large sector of non-governmental organizations, amateurs and activists who deal with heritage on an everyday basis because it is their passion or because they feel that they have a special connection to their country's past. This creates another important group of stakeholders who need to be described and included in this very general division between 'public' and 'expert'.

Therefore, in the next sections, I will use the following understanding of the two terms. Experts are people who deal with heritage on a professional level. This includes academics, scientists, heritage managers, museum workers and historic/natural preservation officers, as well as foresters and workers at governmental organizations. Moreover, experts are also those who decide over the historical policy from the top-down position, such as politicians, local authorities who might not be experts in a sens of knowledge but have the position to decide over heritage). On the other hand, the public are those for whom heritage is not a matter of profession rather a matter of passion - activists, NGO workers, people passionately studying the past of their region and community - or for whom heritage does not play an important role in everyday life - the so-called 'lay men'.

\section{Heritigization as concept}

Within this article, heritage discourse in society is studied using the process of heritigization. The process of heritigization is amplified by the diversity of historical configurations and meanings and it depends on various stakeholders and their approach towards heritage. The term that is used to designate the making of heritage - creating cultural values over places, things, happenings, and marking its importance for society (Murzyn-Kupisz 2012) but also appropriation of certain places, things, events which at a first sight seem to unimportant historically (such as dilapidating contemporary buildings) and presenting them as valuable for specific group of people (Walsh 1992). Within this meaning heritigization is a process of creating heritage that may be acknowledged by the overall public or just small groups of people. 
Heritigization also has additional features and touches upon issues relating to politics and social concerns that are linked to heritage creation:

"The heritagization process carries an emotional resonance about underlying values that maintains social order, collective relationships and sense of belonging. By contributing to cohesiveness with others within a group, individual members gain a sense of wellbeing, even happiness, and build self and mutual confidence. This solidarity enables the smooth operation of the social group, but it also has an ideological element and disciplinary function" (Ashley 2014: 40).

Nevertheless, hertigization is the term mostly used in connection to cultural/historical heritage and marking things or practices from the past as important, as processes that values places, people, things, practices, histories or ideas as an inheritance from the past (Ashley 2014: 40). Here I use the concept of heritigization in a broader sense, to understand and explain this process as a whole thus including both cultural and natural heritage. This derives from the fact that values, and the need to protect the common good, relate to the natural environment and contributes in the same way as cultural heritage.

\section{Top-down heritigization process: Jewish and German heritage and the Rospuda Valley in Poland}

Experts play an important role in disseminating heritage knowledge among the public. They often translate the cultural meaning of places, histories and artefacts to the people. Experts in many cases also from the top-down position determine the value of heritage and decide what is worth preserving and conserving, and what can be forgotten and neglected. Taking into account examples of the remains of Jewish and German heritage in Poland and the fight to preserve the natural heritage of Rospuda Valley, the following section will show how the heritigization process is triggered by the experts and how the public react in situations of heritage promotion and endangered heritage .

\section{German heritage on the so-called 'Recovered Territories' and revival of Jewish culture}

The history of Polish territories is marked by international conflict and national unrest. Second World War has had the strongest impact on Polish lands. Poland, at the centre of the world conflict, experienced the repercussions of war up until today. One important change that was brought to Poland after the Second World War was a change of its borders, transforming it into a ethnically homogeneous country - Poles (Zaremba 2012). Before the Second World War, indeed, Polish borders spread over the lands of today's Ukraine, Belarus and Lithuania. Due to this, Poland was a multicultural and multinational country in which many ethnic and national groups lived. After the Second World War, the situation changed dramatically. Changes at the borders meant that Ukrainians and Lithuanians were no longer living in eastern parts of Poland. Germans who lived in newly adjoined territories of Poland (today's western part of Poland) fled or were expelled from these lands. The territories were resettled by the Poles who came after being expelled from Ukraine or who voluntarily moved to western parts of Poland from its central territories which were devastated by the war (Halicka 2015). Moreover, Poland was inhabited by around three million Jewish people. They lived mostly in central and eastern parts of Poland and had a considerable impact on the culture of these regions. The Holocaust killed more than two million Jews and thousands flew to other countries where they could survive (Zaremba 2012).

Following the war, for many years, Poles perceived their nation as homogenous, consisting 
only of Polish people. During communism, talking about the multiplicity of ethnic and religious groups that lived in Poland was not propagated by the government. It was a time when Poles still needed to prove their rights to the lands in which they inhabited (especially the western parts of Poland) (Mordawski 2015). After the fall of communism, the government was concentrated on country's independence from Russia. Therefore, many studies focused on rewriting the history of Poland and shedding light on the narrative fabricated by the communist propaganda that were propagated by the communist regime (see Halicka 2016). Joining the European Union brought new possibilities to Poland and refreshed the memories of the multiethnic country. Many researchers paid special attention to the forgotten heritage of Jewish people (see Polonsky 2017) and started to study issues connected to the Germans living in western Poland before the Second World War (Nodzyński \& Tureczek 2015, Stachowiak 2015). To do so, they had to intervene in the lives of local communities and introduce them to the neglected past of the people who also lived in Poland.

Thanks to the wide outreach of such projects, Poles could bring back the memories and stories of the people representing different cultures that also influenced the history of their region. Establishment of local and national museums, preparation of cultural events, articles in books and newspapers, as well as actions of restoration and renovation of heritage, influenced the perception of Polish history and resulted in a revival of heritage and stories from the past that were neglected. Moreover, this revival has gone beyond the researchers' expectations; places connected to Jewish inhabitance have been one of the most widely known and visited tourist attractions in cities such as Cracow and Łódż. The Kazimierz district in Cracow, which was largely inhabited by the Jewish community, is an important centre of cultural life. Even Steven Spielberg, inspired by Kazimierz district, filmed Schindler's List there, which had a considerable impact on the popularity of Jewish heritage in Poland. The places inhabited by Jews in the past have been restored and developed into important historic sites. Booming growth in Jewish-themed restaurants, bars, bookstores and souvenir shops can also be seen. This boom has also resulted in a small growth in the Jewish population in Poland. ${ }^{1}$ Jewish people are coming back to the country of their mothers and fathers or those who stayed in Poland are more open to share the stories about their cultural roots.

The occurrence of researchers and films talking about Jewish history in Poland, the publication of many books about it, the restoration of monuments linked to Jewish culture and the building of museums which promote the history of Jews in Poland (e.g. Polin Museum in Warsaw), caused Jewish communities to be more aware of the value of their heritage, even if it was not directly connected to the history of their own nation. Moreover, the social oblivion of Jewish heritage in Poland over the past decades has gradually transferred into a trend in which having some connections with Jewish society is desired (Kołodziejczyk 2014).

A similar situation to the revival of Jewish heritage in Poland took place in the western part of the country. Parts of western territories (Lubuskie province, Pomorskie province), which were adjoined to Poland after the war, were inhabited mostly by the German people. During the communist times, culture and history of their inhabitants had to be forgotten which would present the Polish roots of the region and show that the western parts of Poland were the so-called "Recovered Territories" which were taken by Germans from the Polish nation (Slavs) (Jasiński 2004). Only recently have researchers concentrated on the remains of German culture in western Poland and shown it in the context of historical events and

${ }^{1}$ https://archive.is/20121220125823/, http://www.jewishkrakow.net/en/. 
the present (see Halicka 2015, 2016, Zalewski \& Bielinis-Kopeć 2014). Local communities, encouraged to share their stories of German heritage and their attitude towards it, have been more aware of the impact of German culture on the western lands of Poland. Today, they together with German families who visit their roots, guard this history by protecting the remains of German heritage.

\section{Rospuda Valley and the conflict over the natural environment in Poland}

Rospuda is a small river that flows through north-western Poland, including the northwestern part of the Augustów Primeval Forest wilderness area. The Rospuda Valley is one of the most valuable wetland areas with intact water relations. That is, the bog maintains a steady water level and therefore does not cover the trees or shrubs. It is also under protection due to its rare animals and plants. The musk orchid (Herminium monorchis), has been recorded in the Polish Red Data Book of Plants, and Rospuda Valley is the only Polish locality where this plant can be found. Because of its natural importance, the valley is part of the European Ecological Networks Nature 2000, designated under the Directive on the Conservation of Wild Birds as a Special Bird Protection Area (Szymczuk 2009).

Unfortunately, all that protection and conservation did not save Rospuda from the plans to build the Augustów ring road in the vicinity of its valuable resources. The projected expressway would harm the wildlife of the valley through the pollution and noise emitted, not only during the usage of the road but also during its construction. The situation of natural heritage endangerment at Rospuda resulted in a conflict between experts, the public, and international authorities.

It was first the experts who noticed how fatal the consequences might be for building the bypass road so close to Rospuda Valley (Szymczuk 2009). Because the danger of destroying the wildlife was real, ecological activists, as well as expert scientists such as botanists, zoologists, ecologists and hydrologists, protested against the bypass road and wrote letters to the local authorities that ultimately decided on the road's construction (Szymczuk 2009). The response from the local authorities was negative and they kept building the road. This provoked researchers to put under the spotlight the situation in Rospuda Valley and inform the public about the possibility of losing such an important natural site from the map of Poland. The Polish daily Gazeta Wyborcza launched an online petition, which was signed by over 140,000 people, asking the Polish President Lech Kaczyński to respect the law, preserve the Rospuda Valley and direct the Augustów bypass via a different route (Szymczuk 2009).

Of course, the public response was not that straightforward. On the one hand, the majority of people were convinced by the argumentation of experts. On the other hand, inhabitants of the Rospuda Valley region, especially the town of Augustów, needed the bypass road and they were ready to sacrifice the natural environment to improve their everyday life. Activists and others that felt the need to protect the nature in this region came to Rospuda. They camped in the valley and protested against the decision of the local communities. They were supported by the scientific community and the public, and their determination to save Rospuda grew. The battle over Rospuda lasted for almost three years. In 2006, the first plans showed the bypass road through Rospuda. In 2009, the Polish authorities informed the public that the plans of the highway changed and the alternative route that was chosen would not harm the natural heritage of the region. 
The conflict of the Rospuda Valley was the first such action, inspired by researchers, to have moved the public to protest in the name of natural heritage protection in Poland. The result of such action was not only saving Rospuda Valley from the negative effects of constructing the road, but also creating a general awareness of the importance of natural heritage and the need to safeguard it in Poland.

\section{Heritigization as a process inspired by the public: Kęszyca Leśna and the Bialowieża Forest in Poland}

Although it may seem obvious, experts show the public what is valuable heritage and what is not, but it is often the actions of the public that triggers the protection of heritage. In such cases, the public interprets heritage in their own way, based on their affection towards it, and the social values that it presents. This section focuses on a situation of conflict between experts and the public, which presents heritage as a process of negotiation between both groups.

\section{The end of communist heritage in Poland}

Communism brought a new social system and ideology to Poland and as a consequence of it, new monuments and buildings would represent the power of the communist regime. The ideological meaning of raising such monuments was obvious to Polish society and hence they fought against such authoritative action. Even after the fall of communism in the Polish cities and towns, some can still see the monuments connected to the communist era. These monuments, for many years forgotten or treated as part of the everyday landscape, have recently become a point of conflict between the public and experts.

According to the decision made by the Polish government, all monuments that praise the communist era in Poland should be removed from public spaces. Communist times are treated by the representatives of the government as unequivocally gloomy and bad for the country and society as a whole. And as they are mostly accepted by members of the public, monuments representing some episodes and heroes of communism in Poland are not treated with the same negative attitude by the public. Such a situation happened in Kęczyca Leśna, a small village in western Poland. The village was built by the Germans before the Second World War and then in 1993, it was taken by the Soviets for their troops. Today, the village is inhabited by Poles.

In the centre of the village stands a monument representing a crawling Soviet soldier (Fig. 1). The monument was built during the communist era and it was praising Soviet soldiers who were stationed in the village and in other parts of Poland. After 1993, when the Polish people settled in the village, it still stood in Kęszyca Leśna. None of the new inhabitants thought of removing the monument. Moreover, when it was damaged by tourists or young people, it was renewed by the villagers because, as they said, for them the monument is an important part of the village everyday life and history and they do not imagine that place without it (Gajewska-Ruc 2017).

The monument, according to the government and the Institute of National Remembrance (IPN), represented the oppressive times in Poland and was treated by the inhabitants of Kęszyca Leśna as an important part of the cultural landscape of the village. They perceived it as an integral part of the place in which they lived and it played a significant social role 


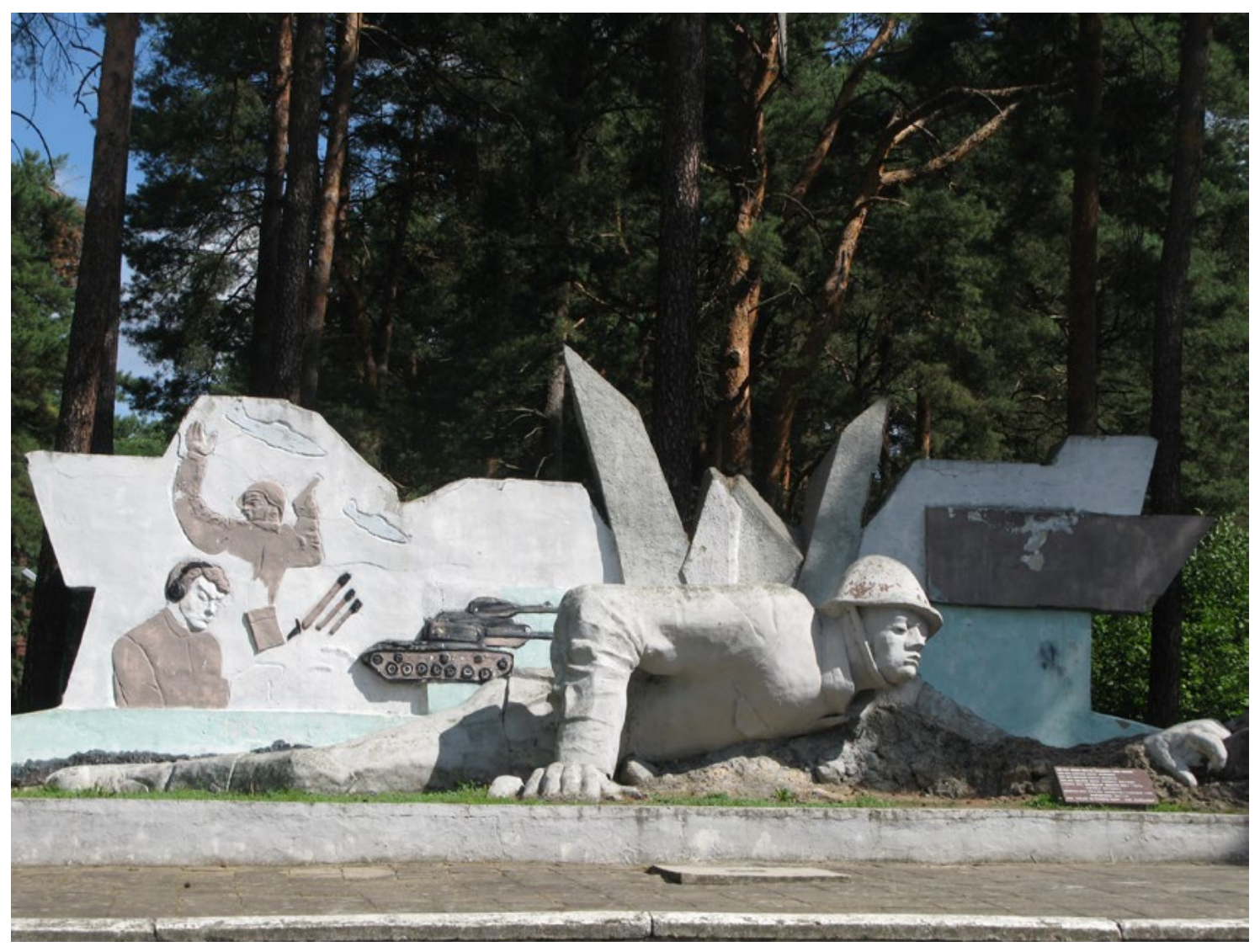

Figure 1. The monument representing a Soviet soldier. Kęszyca Leśna. Photo by Kornelia Kajda.

for them. Namely, it was a meeting point for villagers and a place where they could sit and talk to people. It was the centre of social life for the community who recognize the place as such. Destroying the Soviet soldier's monument would mean a considerable change in the cultural and historical landscape of the village. Therefore, the Polish government and IPN's decision to remove the monument was met with strong disagreement. The inhabitants of Kęczyca Leśna opposed the trials and were ready to fight for it in court. For them, the Soviet soldier was not part of the Soviet regime but part of the history of their village to which they felt bounded (Gajewska-Ruc 2017). IPN allowed the citizens of Kęczyca Leśna to keep the Soviet soldier.

Taking into account the case of Kęczyca Leśna, it may be assumed that the effect of experts' actions was the opposite of what they expected. The experts (mainly politicians) that tried to erase the unwanted history from public spaces made people aware that the remains, after the communist era, may be perceived as heritage and unveiled the social bonds with such heritage. So far, it was only a matter of urban exploration movements (Urbex) which treated the buildings, monuments, and things left by the Soviets in Poland as heritage (see Kobiałka 2016). Therefore, the unintended result of the expert's decision was again a heritigization process of what was not earlier understood by the public as heritage.

\section{The case of Biatowieża Forest}

Białowieża Forest is a unique example of a primeval forest that grew on the European Plain. 
Białowieża Forest stretches around 3,085 km2 on the border between Poland and Belarus. The forest is listed on the UNESCO Heritage Site and the EU Natura 2000 Special Area of Conservation. Białowieża Forest is home to Europe's heaviest land animal, the European bison, and it is thought to be a land of the most abundant diversity of flora and fauna in Europe. It is also an important touristic attraction in Poland and Belarus (Kossak 2016). On the Polish side, Białowieża Forest is visited by approximately 120,000-150,000 tourists annually.

Białowieża Forest has also been a matter of conflict in Poland between various stakeholders, especially representatives of the Polish government, foresters working in National Forests, the European Commission, environmentalists, and the general public. The conflict started on the 26th of March 2016, when the Minister of the Environment in Poland signed a document in which he agreed to cut down the trees in Białowieża Forest on a large scale, including the areas protected by the Natura 2000 programme. The government representatives explained their decision through environmental and protective issues. Namely, the trees were being eaten by the bark beetles and the only way to stop this massive attack and avoid it from spreading was logging the trees. However, the environmentalists and NGOs questioned the decision, explaining how the bark beetles have been in Białowieża Forest for many years and nothing has happened to the forest. Moreover, there are bark beetles in Belarus, but no one wants to cut down the trees there (Szymczuk 2009).

Shortly after the official signature, the workers at the National Forests started the clearance of trees in Białowieża. This step triggered large protests in Poland and as a consequence, many people came to Białowieża Forest to protect the trees with their own body. Environmentalists and activists put their tents in the forest and guarded the area so that the harvesters could not cut down the trees. Moreover, many scientists wrote letters to the government in which they asked the Ministry to explain the situation and explicitly demanded a halt to the clearance because of the harm it was doing to the natural environment in Poland. Despite these actions, the government and representatives of the National Forests did not listen and continued felling trees. Due to this, seven non-governmental organizations decided to file a complaint against the Polish government to the European Commission in which they stated that the decision made by Minister Jan Szyszko breached the EU "Habitats Directive", claiming that each action may have a significant impact on the area of Natura 2000 and will need special protection. However, this did not stop the clearance in Białowieża which day by day divided the specialists from the National Forests and the government from the Polish public. This conflict presented an enormous chasm which had existed in Poland over natural heritage and business but had been hidden from the general public so far. Information about Białowieża was covered on the main news channels in Poland, informing the public on the government's position each day. In many cities, NGOs organized discussions about Białowieża which ended in protests against the government's actions. Fighting for Białowieża Forest also influenced private companies that used wood. Many of these companies declared that they would not buy the wood coming from Białowieża, and the companies which bought that wood were boycotted by their clients. The conflict over natural heritage transformed into a huge conflict with the government and representatives of the National Forests.

The situation in Białowieża Forest also largely influenced the notion of the 'expert' in Polish society. In the end, the public did not know who to trust or who was telling the truth about the situation in the forest. Nonetheless, most of the Polish people were strongly against 
the logging, especially the old-growth trees (Kozińska 2017). Białowieża Forest, had to be especially protected; there was no Polish agreement on the devastation of significant natural heritage. Although Białowieża Forest is a significant place for tourism, and its heritage is valued among the Polish and international public, it was the expert's decision of felling the trees that made Polish society more aware of the history of Białowieża Forest and its multiple natural values. A situation of conflict and disagreement with the decision caused Polish society to take matters into their own hands, showing that heritage was more important to them than any decisions made on their behalf by the Polish government or experts. This situation presents how the process of heritigization may be an unintended effect of expert decision making.

\section{Conclusions}

Public and expert voices may differ considerably in the of heritage. Although it may be assumed that experts are those who mark the points under discussion and decide on the meanings of heritage, the case studies derived from Poland show that it is not so straightforward. It is often the public that determines social understanding of heritage and its treatment in opposition to experts' decisions - as in the case of Soviet heritage in Poland or the Białowieża Forest. However, experts' actions often trigger society to take care of their heritage. Experts also inspire the public to notice the values of things, places and stories - as in the case of Jewish and German heritage. In this case, the heritigization process was inspired by researchers and their will to rewrite the forgotten multicultural past of Poland. The public, inspired by the experts, could feel the collective relationships and sense of belonging (Ashley 2014: 40) to the culture and nature of the country that they live in.

The meaning of heritage and attitudes toward it cannot be determined by one group - the public or the experts. Clearly, it is not a matter of whether the decisions made from above will always be the right choice or completely accepted. Yet, heritage is an issue that will always need ongoing discussion, which can only be created in an atmosphere of negotiation.

\section{References}

Ashley, S.L.T. 2014. Re-telling, Re-cognition, Re-stitution: Sikh Heritagization in Canada. Cultura: International Journal of Philosophy of Culture and Axiology 11, 39-58.

Carman, J. 2005. Against Cultural Property: Archaeology, Heritage and Ownership. Bristol: Bristol Classical Press.

CFP: Heritagization and heritage sustainability: reflection and prospective, Lisbon, 27-29. November2014.Accessed12/08/2018.https://respatrimoni.files.wordpress.com/2014/03/ call-for-papers_-patrimonializac3a7c3a3o-e-sustentabilidade-do-patrimc3b3nio_2014.pdf. Deisser, A.M \& M. Nuuguna, 2016. Conservation of Natural and Cultural Heritage in Kenya. London: ULC Press.

GajewskA-Ruc, A., 2017. Mieszkańcy Kęszycy Leśnej stoją murem za żołnierzem. Accessed 12/08/2018.https://gazetalubuska.pl/mieszkancy-keszycy-lesnej-stoja-murem-zazolnierzem-wideo-zdjecia/ar/12160172.

GEORgE, E.W., 2010. Intangible cultural heritage, ownership, copyrights, and tourism. International Journal of Culture, Tourism and Hospitality Research 4, 376-388. https://doi. org/10.1108/17506181011081541.

Halicka, B., 2015. Polski Driki Zachód: Praymusowe migracje i kulturowe oswajanie Nadodræa 19451948. Kraków: Universitas. 
Halicka, B. (ed.), 2016. Mój dom nad Odrą. Pamiętniki osadników Ziem Zachodnich po 1945. Kraków: Universitas.

Hodder, I. 2010. Cultural Heritage Rights: From Ownership and Descent to Justice and Well-being. Anthropological Quarterly 83, 861-882.

Harrison, R. 2013. Heritage: Critical approaches. Abingdon and New York: Routledge.

JAsIŃSKI, J., 2004. Czy powinniśmy odcinać sie_od pojęcia Ziemie Odzyskane?. Echa Przesžtośsi $5,315-320$.

KIDDEY, R. 2017. Homeless heritage. Collaborative social archaeology as therapentic practice. Oxford: Oxford University Press.

KobiaŁKA, D. 2016. UrbEx: archeologiczny flâneuryzm a multitemporalność dziedzictwa. Biografia Archeologii 2, 3-12.

KobYLIŃski, Z., 2011. Czym jest, komu jest potrzebne i do kogo należy dziedzictwo kulturowe? Mazowsze: Studia Regionalne 7, 21-47.

KoŁodziejCZYK, M., 2014. Moda na żydowskość: Powrót Żydów. Accessed 09/09/2018.

https://www.polityka.pl/tygodnikpolityka/spoleczenstwo/1596469,1,moda-nazydowskosc.read $\backslash$.

Kossak, S., 2016. Saga Pusz̨̧y Biatowieskiej. Warsaw: Marginesy.

Kozińska, A. 2017. Wycinka Puszçy Biatowieskiej. Polacy: to nie kornik jest problemem. Accessed 11/09/2018.

https://wiadomosci.wp.pl/wycinka-puszczy-bialowieskiej-polacy-to-nie-kornik-jestproblemem-6153593486898817a.

La Follette, L. (ed.), 2013. Negotiating Culture: Heritage, Ownership, and Intellectual Property. Amherst: University of Massachusetts Press.

MArgry, P.J. 2011. Mamorizing a controversial politician: The "heritagization" of a materialized vox populi, in: P. J. Margry \& C. SÁnChez-Carretero (eds), Grassroots Memorials: The Politics of Memorializing Traumatic Death. New York: Berghahn Books, 319-354.

MiLOŠEvić, A. 2017. Historicizing the present: Brussels attacks and heritagization of spontaneous memorials. International Journal of Heritage Studies 24, 53-65. doi: 10.1080/13527258.2017.1362574.

Mordawski, H., 2015. Ziemie Odzyskane 1945-1956. Brzezia Łąka: Wydawnictwo Poligraf.

Murzyn-KupIsz, M. 2012. Driedzictwo kulturowe a rozwój lokalny. Kraków: Wydawnictwo Uniwersytetu Ekonomicznego w Krakowie.

NodzyŃSki, T. \& TureCZeK M. (eds), 2015. Ziemia Lubuska: Dziedzictwo kulturowe i tożsamość regionu w perspektymie powojennego siedemdriesięciolecia. Zielona Góra: Polskie Towarzystwo Historyczne.

Polonsky, A., 2017. Nieznane polsko-żydowskie dziedzictwo. Profesor Antony Polonsky w rozmowie z. Anna Jarmusiewicz: Warszawa: PWN.

Stachowiak, A. 2015. Niemieckie cmentarze na Ziemiach Zachodnich jako miejsca niepamięci. Zeszyty Naukowe Uniwersytetu Jagiellonskiego Prace Etnograficzne 43, 123-140. doi:10.4467/22999558.PE.15.010.4497.

SzymczuK, R. 2009. Zwycięstwo nad Rospudą - Obwodnica Augustowa a Natura 2000. Drikie Życie 5: 179. Accessed 10/09/2018.

https://www.ekologia.pl/srodowisko/ochrona-srodowiska/zwyciestwo-nad-rospuda,8992.html. Walsh, K. 1992, The Representation of the Past: Museums and Heritage in the in the Postmodern World. London: Routledge Press.

ZALEwski, P. \& Bielinis-Kopeć, B. (eds), 2014. Spoteczeństwo obywatelskie a ochrona zabytków na pograniczu polsko-niemieckim. Gubin: Warsztat Konserwatora Gubińskiej Fary.

Zaremba, M. 2012. Wielka trwoga. Kraków: Znak. 